\title{
NUTRACEUTICAL PROPERTIES AND HEALTH-PROMOTING BIOLOGICAL ACTIVITIES OF FRUITS OF WATERMELON CULTIVARS WITH DIFFERENT ORIGINS
}

\author{
TERESA CASACCHIA ${ }^{1}$, ADRIANO SOFO ${ }^{2}$, CLAUDIA-CRINATOMA $^{3 *}$, DOINA DRĂGĂNESCU ${ }^{4}$, \\ BOGDAN TIȚA $^{3}$, GIANCARLO ANTONIO STATTI ${ }^{1}$ \\ ${ }^{1}$ Department of Pharmacy, Health and Nutritional Sciences, University of Calabria, Arcavacata di Rende, 87030, Italy \\ ${ }^{2}$ School of Agricultural, Forestry, Food and Environmental Sciences, University of Basilicata, Via dell'Ateneo Lucano no. 10 , \\ 85100, Potenza, Italy \\ ${ }^{3}$ Faculty of Pharmacy, "Vasile Goldiș” Western University of Arad, 87 Liviu Rebreanu Street, Arad, Romania \\ ${ }^{4}$ Faculty of Pharmacy, "Carol Davila” University of Medicine and Pharmacy, 6 Traian Vuia Street, Bucharest, Romania
}

*corresponding author: claudiatoma2004@yahoo.com

Manuscript received: December 2019

\begin{abstract}
This study was focused on biologically active compounds extracted from pulp and rind of watermelon fruits (Citrullus lanatus (Thunb.) Matsum. \& Nakai, 1916) cultivars with different origins (Italy, Costa Rica, Brazil, Ecuador and Santana-Romania). Total polyphenols and flavonoids, lycopene and L-citrulline, were extracted from the pulp and their content determined spectrophotometrically. L-citrulline was also measured in the rind. In addition, the determination of some biological activities (antioxidant activity and inhibition of the amylase and lipase enzymes) of watermelon pulp was carried out. The examined pulp of the watermelon cultivars revealed to have a high content of antioxidants (e.g., lycopene up to $39.68 \pm 0.13 \mu \mathrm{g} / \mathrm{g} \mathrm{FW}$ in an Italian cultivar) and bioactive molecules (e.g., L-citrulline up to $0.87 \mathrm{mg} / \mathrm{g} \mathrm{FW}$ in the Ecuadorian cultivar). Watermelon rind had higher contents of L-citrulline (up to $2.60 \mathrm{mg} / \mathrm{g} \mathrm{FW}$ ) compared to pulp. The comparisons between watermelons cultivars revealed the significant inhibitory of lipase (values ranging from 117.10 to $312.12 \mathrm{IC}_{50}$ ) and $\alpha$-amylase (values ranging from 145.52 to $322.13 \mathrm{IC}_{50}$ ), so confirming their health-promoting potential. All these factors taken together make watermelon a high-value food with evident benefits on human health. The results of this study could facilitate the discovery, improvement and utilization of new watermelon cultivars with high nutraceutical properties.
\end{abstract}

\section{Rezumat}

Acest studiu s-a concentrat asupra compușilor biologic activi extrași din pulpa și coaja de fructe de pepene verde (Citrullus lanatus (Thunb.) Matsum. \& Nakai, 1916) din soiuri de origine diferită (Italia, Costa Rica, Brazilia, Ecuador și SantanaRomânia). S-au extras polifenoli și flavonoide, licopen și L-citrulină din pulpă și conținutul lor a fost determinat spectrofotometric. De asemenea s-a determinat și L-citrulina din coajă. În plus, a fost efectuată determinarea unor activităţi biologice (activitatea antioxidantă și inhibarea enzimelor amilază și lipază) din pulpa de pepene. Pulpa de soiuri de pepene verde examinată a arătat că are un conținut ridicat de antioxidanți (licopen până la 39,68 $\mu \mathrm{g} / \mathrm{g}$ FW într-un soi italian) şi molecule bioactive (de exemplu L-citrulină până la $0,87 \mathrm{mg} / \mathrm{g}$ FW într-un soi ecuadorian). Coaja de pepene are un conţinut mai mare de L-citrulină (până la $2,60 \mathrm{mg} / \mathrm{g} \mathrm{FW}$ ) comparativ cu pulpa. Comparațiile dintre varietățile de pepene verde au evidențiat

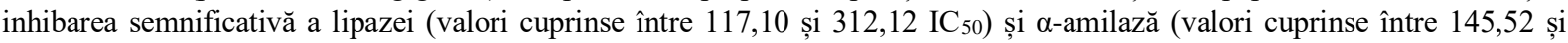
322,13 IC 50), confirmând astfel potențialul lor de promovare a sănătății. Toți acești factori fac din pepenele verde un aliment de mare valoare, cu beneficii evidente asupra sănătătii umane. Rezultatele acestui studiu ar putea facilita descoperirea, ameliorarea şi utilizarea unor noi soiuri de pepene verde cu proprietăţi nutritive mari.

Keywords: $\alpha$-amylase, antioxidant activity, citrulline, Citrullus lanatus L., lipase, polyphenols

\section{Introduction}

The watermelon (Citrullus lanatus (Thunb.) Matsum \& Nakai, 1916) belongs to the Cucurbitaceae family (Cucurbitaceae Juss.), order Violales (Cucurbitales according to the classification APG III) which includes about 118 genera and 825 species [23]. Historically, the first collection of Cucurbitaceae was documented 5000 years ago in Egypt and they spread to other parts of the world [48]. Currently, China is the leading producer of Cucurbitaceae, followed by Turkey, the United States, Iran and the Republic of Korea [32]. Within Cucurbitaceae, the genera Cucumis, Citrullus and Cucurbita are those considered of great agronomic and economic importance, and only the first two bear the common name of "melon" [43]. The genus Citrullus includes four diploid species $(2 n=22)$ those are mainly cultivated in Africa, Asia and the Mediterranean [25] and consist of two varieties of watermelons: $C$. 
lanatus var. lanatus and C. lanatus var. citroides (Bailey) Mansf.

In the recent years, consumers are more and more aware of their health-promoting plant-based food because of the heavy impact of the non-transmissible diseases, such as hypertension, diabetes, different forms of cancer, and cardiovascular disease, and, for this reason, nowadays there is a strong demand for high quality fruit and vegetables [10]. The interest in the study of edible medicinal plants having phytotherapeutic and food-supplementing properties is booming, and to date there are over 170,000 identified secondary metabolites with a potential medicalpharmaceutical and herbalist use.

In our specific case, watermelon is an interesting source of L-citrulline [27], a non-proteogenic natural aminoacid, precursor of L-arginine in mammals [46]. Lcitrulline is also involved in the production of endogenous nitroxide (NO) [18] in the arginine (nitrite + nitrate) pathway. NO is considered essential for regulating vasodilatation, immune responses, neurotransmission and adhesion of platelets and leucocytes $[6,31]$. In addition, watermelon is a rich natural source of lycopene, a red carotenoid of great interest because of its antioxidant capacity and potential health benefits, widely used in natural medicine $[3,37]$. Besides its antioxidant and antibacterial activity, mainly due to the high content of polyphenols and lycopene [20], watermelon has been found to have inhibitory effects on both pancreatic lipase (PL) and $\alpha$-amylase (PA), and so they could be valuable therapeutic agent for the treatment of diet-induced obesity [28, 38].

As the knowledge on the metabolites with nutraceutical properties in watermelon is still poorly known, it is important to characterize different genotypes to identify their nutritional value based on different cultivars, sampling area and ripening stages of fruits [41]. On this basis, this study was focused on some biologically active compounds extracted from the pulp and rind of watermelons with different origins (Italy, Costa Rica, Brazil, Ecuador and Santana-Romania). Some phytochemical markers that have a strong interest as nutraceutical compounds, such as total polyphenols and flavonoids, lycopene and L-citrulline, were investigated. In addition, the determination of some biological activities (antioxidant activity, and inhibition of the amylase and lipase enzymes) of watermelon pulp was carried out. The results of this study could facilitate the discovery, improvement and utilization of new watermelon cultivars with higher nutraceutical properties.

\section{Materials and Methods}

\section{Plant material}

Samples of watermelon fruits (Citrullus lanatus (Thunb.) Matsum \& Nakai, 1916) were supplied by a local dealer who, through his own network of producers, was able to carefully monitor the collection period and its provenience (Table I).

Table I

Characteristics of the watermelons analysed (2015 2016 sampling years)

\begin{tabular}{|l|c|c|}
\hline \multicolumn{1}{|c|}{ Origin } & Harvest period & Legend \\
\hline Brazil & January & CL-B \\
\hline Costa Rica & February & CL-CR \\
\hline Ecuador & March & CL-E \\
\hline Latina - Italy & July & CL-L \\
\hline Lamezia Terme - Italy & July & CL-LM \\
\hline Crotone - Italy & July & CL-KR \\
\hline Santana-Romania & June & CL-RG \\
\hline Santana-Romania & July & CL-RL \\
\hline Santana-Romania & September & CL-RS \\
\hline
\end{tabular}

The samples were received in the laboratory between January and July 2015. For each sample, visual and morphological evaluations were carried out and the integrity of the fruit was checked. The colour of the outer skin ranged from light green to dark green, while that of the pulp varied from pink to dark red to golden yellow.

From a visual examination, the watermelon coming from Brazil turned out to be spherical in shape, with a light-striped green outer colour, light pink pulp, yellowish seeds with a typical teardrop shape, and an average weight $6 \mathrm{~kg}$. The watermelon of Costa Rica presented, instead, spherical shape, light green skin streaked with dark green, average weight $5-6 \mathrm{~kg}$, red pulp, rich in numerous flat seeds. The watermelon from Ecuador presented an oval shape, a light green skin, main weight $7 \mathrm{~kg}$, and a red pulp rich in seeds. Watermelons from Romania showed a roundish shape, dark green skin with streaks of light green and more or less intense golden pulp. For Romanian watermelons, it was possible to evaluate its phytochemical and biological characteristics in different ripening periods. Finally, Italian watermelons from three different locations (Latina, Lamezia Terme and Crotone) had common characteristics, such as oblong shape, dark green skin with streaks of two colours, weight of about $10-12 \mathrm{~kg}$, and bright red flesh, rich in seeds.

Pulp extractions

The fruits were cut transversely to separate the pulp from the rind. Pulp was cut into smaller pieces and extracted according to Toma et al. [42], using Naviglio ${ }^{\circledR}$ extractor (Nuova Estrazione S.a.s., Naples, Italy) an equipment for solid-liquid extraction working at room temperature based on a gradient of pressure between the inner and the outlet of solid matrix. The values of extraction yield are shown in Table II. Pulp extracts were used for all the measurements, excepting for lycopene and L-citrulline determinations, where fresh pulp was used. 
Extraction yield of watermelon pulp samples

\begin{tabular}{|c|c|c|c|}
\hline Sample & Plant weight (g FW) & Extract weight $\mathbf{( g ~ F W )}$ & Extraction yield (\%) \\
\hline CL-B & 1589.37 & 290.37 & 18.26 \\
\hline CL-CR & 2237.87 & 323.93 & 14.47 \\
\hline CL-E & 835.37 & 255.03 & 30.53 \\
\hline CL-L & 792.05 & 158.02 & 19.95 \\
\hline CL-LM & 577.00 & 154.00 & 26.68 \\
\hline CL-KR & 580.5 & 161.00 & 27.33 \\
\hline CL-RG & 582.5 & 160.45 & 27.54 \\
\hline CL-RL & 790.14 & 203.14 & 25.71 \\
\hline CL-RS & 894.25 & 216.50 & 24.21 \\
\hline
\end{tabular}

Chemical analysis

Chemical reagents. Chlorogenic acid, quercetin, FolinCiocâlteu reagent, aluminium chloride, ascorbic acid, Trolox, 2,2-diphenyl-1-picrylhydrazyl (DPPH), $\beta$ carotene, $p$-nitrophenyl octanoate, 3,5-dinitrosalicylic acid, linoleic acid, lycopene, L - citrulline, Tween 20, lipase porcine pancreas, $\alpha$-amylase pig pancreas, diacetyl-monoxime, 3,5-dinitrosalicylic acid were purchased from Sigma-Aldrich $\mathrm{SpA}$ (Milan, Italy). Ethanol, $\mathrm{NaOH}$, $\mathrm{HCl}, \mathrm{H}_{2} \mathrm{SO}_{4}$, and $\mathrm{H}_{3} \mathrm{PO}_{4}$ were purchased from VWR International s.r.l. (Milan, Italy), while all the other reagents were produced by Carlo Erba (Milan, Italy) and where used without further purification.

Total phenols determination. An aliquot of $20 \mathrm{~mL}$ of each extract obtained from watermelon pulp were dissolved in $10 \mathrm{~mL}$ of an ethanol/ $\mathrm{HCl}$ mixture solution $(95: 5, \mathrm{v} / \mathrm{v})$ and kept at $60^{\circ} \mathrm{C}$ (water bath) for $1 \mathrm{~h}$, allowed to cool to room temperature and then homogenized. The solution $(200 \mu \mathrm{L})$ was introduced into the screw test tubes, $1.0 \mathrm{~mL}$ of Folin-Ciocâlteu reagent was added and, after $3 \mathrm{~min}, 1.0 \mathrm{~mL}$ of $\mathrm{Na}_{2} \mathrm{CO}_{3}$ (7.5\%) was added. The tubes were kept at $40^{\circ} \mathrm{C}$ (water bath) for $30 \mathrm{~min}$. Absorption at $726 \mathrm{~nm}$ was measured (model Lambda 40 UV/VIS Spectrophotometer; PerkinElmer, Waltham, MA, United States) and total phenol content expressed in mg of CAE (chlorogenic acid equivalents) per $\mathrm{g}$ of fresh material (FW). For the calculation of the total phenol content, it was necessary a calibration curve obtained from known concentrations of chlorogenic acid (10 to $1000 \mu \mathrm{g} / \mathrm{mL}$ ).

Total flavonoids determination. The total flavonoid content was evaluated through a colorimetric assay based on the formation of a flavonoid-aluminium complex. $1 \mathrm{~mL}$ of ethanol was added to $2 \mathrm{~mL}$ of watermelon pulp extract and, after $5 \mathrm{~min}$ of incubation, a $2 \%(\mathrm{w} / \mathrm{w})$ aqueous solution of $\mathrm{AlCl}_{3}$ was added. The mixture was kept in the dark for $15 \mathrm{~min}$. The calibration curve was determined with seven standard concentrations ranging from 25 to $900 \mu \mathrm{g} / \mathrm{mL}$. The principle of the method is based on the formation of a flavonoid-aluminium complex with maximum absorption at $430 \mathrm{~nm}$. The total content of flavonoids was expressed in $\mathrm{mg} \mathrm{QE}$ (quercetin equivalent) per $\mathrm{g}$ of fresh material $(\mathrm{FW})$.
Lycopene determination. The content of lycopene was determined using the method of Davis et al. with some modifications [11]. Approximately $0.6 \mathrm{~mL}$ of fresh pulp were measured and treated with $5 \mathrm{~mL}$ of $1 \%$ (w/w) ascorbic acid, $5 \mathrm{~mL}$ of $95 \% \mathrm{EtOH}$ and $10 \mathrm{~mL}$ of hexane. The samples were centrifuged at $400 \mathrm{rpm}$ for $15 \mathrm{~min}$ at $4^{\circ} \mathrm{C}$. Subsequently, $3 \mathrm{~mL}$ of distilled water were added and kept at room temperature to allow separation of the phases. The absorbance of the upper phase was measured at $503 \mathrm{~nm}$ spectrophotometrically. The white reading was carried out with hexane. The lycopene content was evaluated using the following equation:

Lycopene $(\mathrm{mg} / \mathrm{kg}$ pulp $)=\left(\mathrm{ABS}_{503} \times 31.2\right) /(\mathrm{pulp}(\mathrm{kg}))$. L-citrulline determination. For the determination of $\mathrm{L}$ citrulline, the protocol of Cheng et al. was optimized [9]. Fresh pulp and rind of watermelon $(3 \mathrm{~g})$ were extracted with $15 \mathrm{~mL}$ solution prepared from methanol and $\mathrm{HCl} 6 \mathrm{M}(9: 1, \mathrm{v} / \mathrm{v})$ at $55^{\circ} \mathrm{C}$ for $20 \mathrm{~min}$. The sample was treated with $5 \mathrm{~g}$ of filtered active carbon and subsequently diluted with distilled water. To $1 \mathrm{~mL}$ diluted solution, $4 \mathrm{~mL}$ of distilled water, $2 \mathrm{~mL}$ of a mixture $(3: 1, \mathrm{v} / \mathrm{v})$ of sulfuric acid and phosphoric acid, and $0.25 \mathrm{~mL}$ dyacetyl-monoxime were added. The obtained solution was stirred and heated to $100^{\circ} \mathrm{C}$ for $30 \mathrm{~min}$. The concentration of the final sample was determined spectrophotometrically at $490 \mathrm{~nm}$. The L-citrulline content was calculated using a calibration curve of a standard citrulline sample, using the following equation:

L-citrulline $(\mathrm{g} / \mathrm{kg}$ pulp $)=\left(0.1288 \mathrm{ABS}_{490}+0.0044\right) \times$ dilution factor.

\section{Total antioxidant activity}

$\mathrm{DPPH} \bullet$ radical scavenging activity. The radical scavenging activity was determined by the dosage of 1,1-diphenyl-2-picryl-hydrazil (DPPH•) using a method adapted from Marrelli et al. [29]. To $800 \mu \mathrm{L}$ of an alcoholic solution of DPPH• $\left(1 \times 10^{-4} \mathrm{M}\right) 200 \mu \mathrm{L}$ of watermelon pulp extract were added at different concentrations $(5,2.5,1.25,0.5,0.25$, and $0.125 \mathrm{mg} / \mathrm{mL})$. The Trolox (Sigma-Aldrich St. Louis, USA) was used as the positive control at the same concentrations of the samples, whereas an alcoholic solution of $1 \times 10^{-4} \mathrm{M}$ $\mathrm{DPPH} \cdot$ was used as the negative control, and the 
extract was replaced by a corresponding aliquot of the appropriate solvent. The samples thus obtained were placed in the dark for $30 \mathrm{~min}$ and then read spectrophotometrically at $517 \mathrm{~nm}$. The antioxidant activity of the extract (and of the Trolox) was calculated in relation to the decrease of the absorbance that was observed following the capture of the radical, more precisely as a percentage of inhibition in the formation of the DPPH • radical, according to the following equation:

$$
\begin{gathered}
\mathrm{DPPH} \cdot \text { radical scavenging activity }(\%)= \\
{\left[\left(\mathrm{ABS}_{\mathrm{c}}-\mathrm{ABS}_{\mathrm{e}}\right) / \mathrm{ABS}_{\mathrm{c}}\right] \times 100,}
\end{gathered}
$$

where $\mathrm{ABS}_{\mathrm{c}}$ is the absorbance of control and $\mathrm{ABS}_{\mathrm{e}}$ is the absorbance of the extract.

$\beta$-carotene bleaching test $(B C B)$. The $\mathrm{BCB}$ was carried out by adding $1.5 \mathrm{~mL}$ of $\beta$-carotene solution $(0.5$ $\mathrm{mg} / \mathrm{mL}$ ) in chloroform to $0.04 \mathrm{~mL}$ linoleic acid and $0.4 \mathrm{~mL}$ of Tween 20 . The chloroform was removed by evaporation with a Rotavapor R-220 SE (BÜCHI Labortechnik AG, Flawil, Switzerland) at $40^{\circ} \mathrm{C}$ for $10 \mathrm{~min}$. Subsequently, $150 \mathrm{~mL}$ of distilled water were added slowly to obtain a homogeneous emulsion. To $5 \mathrm{~mL}$ of this latter, $200 \mu \mathrm{L}$ watermelon pulp extract were added and three spectrophotometric readings at $470 \mathrm{~nm}$ were carried out at $\mathrm{t}=0 \mathrm{~min}$, at $=30 \mathrm{~min}$ and at $\mathrm{t}=60 \mathrm{~min}$. As a positive control, the watersolubilized Trolox was used at the concentrations of the samples, while the negative control was composed only by the previously described emulsion, in which the fraction of the extract was replaced by an equal amount of water. The antioxidant activity of the extract (and of the Trolox) was expressed as a percentage of inhibition of $\beta$-carotene oxidation according to the equation of Kumazawa:

$$
\mathrm{AA} \%=\left[\left(\mathrm{ABS}_{0}-\mathrm{ABS}_{\mathrm{x}}\right) / \mathrm{ABS}_{0}\right] \times 100,
$$

where $\mathrm{ABS}_{0}$ is the absorbance of the control at $\mathrm{t}=0$ min and $\mathrm{ABS}_{\mathrm{x}}$ is the absorbance of the sample at $\mathrm{t}=$ $30 \mathrm{~min}$ and $\mathrm{t}=60 \mathrm{~min}$.

Determination of biological activities

Lipase inhibition. The inhibition of pancreatic lipase activity is evaluated spectrophotometrically using the $p$-nitrophenyl octonoate ( $p$-NPO), a chromogenic ester, as a substrate. The activity of the enzyme was measured by monitoring the hydrolysis of $p$-NPO. The released yellow chromogen, $p$-nitrophenol, was quantified according to Bendicho et al. [4]. The orlistat (tetrahydro-lipostatin) was used as a positive control. Orlistat irreversibly inhibits about $30 \%$ of the gastrointestinal and pancreatic lipase activity present in the intestinal lumen.

An aqueous solution ( $3 \mathrm{mg} / \mathrm{mL}$ ) was prepared from raw type II swine pancreas (Conforti et al., 2012). A $7.5 \mathrm{mmol} / \mathrm{L} p$-NPO solution was then prepared in dimethyl sulfoxide (DMSO). The composition of the reaction mixture was as follows: $100 \mu \mathrm{L}$ of $7.5 \mathrm{mmol} / \mathrm{L}$ of $p$-NPO, $4 \mathrm{~mL}$ of Tris-HCl buffer $(\mathrm{pH}=8.5), 100 \mu \mathrm{L}$ of extract (concentration 400, 250, 100, 55, 30, 5, 2, $0.8,0.20,0.05 \mathrm{mg} / \mathrm{mL}$ ) and $100 \mu \mathrm{L}$ of enzymatic solution. The mixture was incubated at $37^{\circ} \mathrm{C}$. In the control, the extract was replaced with the same volume of DMSO. An empty sample without the enzyme was prepared for each extract. Orlistat was used for comparison. Pancreatic inhibitory activity was calculated using the following formula:

\section{Determination of biological activities}

Lipase inhibition. The inhibition of pancreatic lipase activity is evaluated spectrophotometrically using the $p$-nitrophenyl octonoate ( $p$-NPO), a chromogenic ester, as a substrate. The activity of the enzyme was measured by monitoring the hydrolysis of $p$-NPO. The released yellow chromogen, $p$-nitrophenol, was quantified according to Bendicho et al. [4]. The orlistat (tetrahydro-lipostatin) was used as a positive control. Orlistat irreversibly inhibits about $30 \%$ of the gastrointestinal and pancreatic lipase activity present in the intestinal lumen.

An aqueous solution ( $3 \mathrm{mg} / \mathrm{mL}$ ) was prepared from raw type II swine pancreas (Conforti et al., 2012). A $7.5 \mathrm{mmol} / \mathrm{L} p$-NPO solution was then prepared in dimethyl sulfoxide (DMSO). The composition of the reaction mixture was as follows: $100 \mu \mathrm{L}$ of $7.5 \mathrm{mmol} / \mathrm{L}$ of $p$-NPO, $4 \mathrm{~mL}$ of Tris-HCl buffer $(\mathrm{pH}=8.5), 100 \mu \mathrm{L}$ of extract (concentration 400, 250, 100, 55, 30, 5, 2, $0.8,0.20,0.05 \mathrm{mg} / \mathrm{mL}$ ) and $100 \mu \mathrm{L}$ of enzymatic solution. The mixture was incubated at $37^{\circ} \mathrm{C}$. In the control, the extract was replaced with the same volume of DMSO. An empty sample without the enzyme was prepared for each extract. Orlistat was used for comparison. Pancreatic inhibitory activity was calculated using the following formula:

Lipase inhibition $(\%)=\left[\left(\mathrm{ABS}_{\mathrm{c}}-\mathrm{ABS}_{0}\right) / \mathrm{ABS}_{\mathrm{c}}\right] \times 100$, where $\mathrm{ABS}_{0}$ is defined as the absorbance of the enzymatic activity without sample and $\mathrm{ABS}_{\mathrm{c}}$ is the absorbance of a test sample with the enzyme.

$\alpha$-amylase inhibition. Inhibition of the $\alpha$-amylase enzyme was evaluated using a modified version of the method used by Kwon et al. [22]. To $100 \mu \mathrm{L}$ of the extract solution (concentrations 400, 250, 100, 55, 30, $15,5,2,0.8,0.20,0.05 \mathrm{mg} / \mathrm{mL}$ ) were added $500 \mu \mathrm{L}$ of an enzymatic solution $(0.5 \mathrm{mg} / \mathrm{mL})$ in cold distilled water and $500 \mu \mathrm{L}$ of a starch solution at $1 \%(\mathrm{v} / \mathrm{v})$ in $0,01 \mathrm{M}$ phosphate buffer at $\mathrm{pH}$ 7.0. The reaction mixture was incubated at $37^{\circ} \mathrm{C}$ for $5 \mathrm{~min}$, and the reaction was interrupted after the addition of $1 \mathrm{~mL}$ of reagent dye DNA (3,5-dinitrosalicylic acid and 1\% of potassium sodium tartrate in $2 \% \mathrm{NaOH} 0.4 \mathrm{M}$ ). The reaction mixture was incubated at $100^{\circ} \mathrm{C}$ for 5 min and the absorbance content measured at $540 \mathrm{~nm}$. The $\alpha$-amylase inhibitory activity was calculated using the following formula:

$\alpha$-amylase inhibition $(\%)=\left[\left(\mathrm{ABS}_{\mathrm{c}}-\mathrm{ABS}_{0}\right) / \mathrm{ABS}_{\mathrm{c}}\right] \times 100$, where $\mathrm{ABS}_{0}$ is defined as the absorbance of the enzymatic activity without sample and $\mathrm{ABS}_{\mathrm{c}}$ is the 
absorbance of a test sample with the enzyme. The acarbose concentration and plant extracts necessary to inhibit $50 \%$ of $\alpha$-amylase activity was defined as the $\mathrm{IC}_{50}$ value. Inhibitory activities of $\alpha$-amylase of plant extracts and of acarbose were calculated and the $\mathrm{IC}_{50}$ values determined.

Statistical analysis

The number of the replicates for each measurement were indicated in table and figure captions. Data were analysed using SAS version 9.2 (SAS Institute Inc., Cary, NC, USA). Analysis of variance (ANOVA) was performed using the PROC GLM procedure of the software that uses the method of least squares to fit general linear models. PROC GLM enables to specify any degree of interaction (crossed effects) and nested effects, and also provides for polynomial, continuousby-class, and continuous-nesting-class effects. Significant differences among means were determined at $\mathrm{p} \leq 0.05$, according to $t$ test.

\section{Results and Discussion}

\section{Total phenols and antioxidant activity}

From the survey carried out on watermelon pulp, it emerges that the total polyphenol content was significantly higher in the CLKR Italian fruits, followed by the Ecuadorian (CLE) and Costa Rican (CLCR) ones (Table III).

Table III

Total polyphenols and total flavonoids in

\begin{tabular}{|l|c|c|}
\hline Sample & $\begin{array}{c}\text { Total phenols } \\
\text { (mg CAE/g FW) }\end{array}$ & $\begin{array}{c}\text { Total flavonoids } \\
\text { (mg QE/g FW) }\end{array}$ \\
\hline CLB & $14.98 \pm 0.13^{\mathrm{d}}$ & $5.32 \pm 0.08$ \\
\hline CLCR & $16.07 \pm 0.09^{\mathrm{d}}$ & $7.89 \pm 0.40$ \\
\hline CLE & $17.50 \pm 0.32^{\mathrm{b}}$ & $5.37 \pm 0.04$ \\
\hline CLL & $16.73 \pm 0.80^{\mathrm{c}}$ & $3.41 \pm 0.02$ \\
\hline CLLM & $15.84 \pm 0.15^{\mathrm{d}}$ & $2.79 \pm 0.05$ \\
\hline CLKR & $18.70 \pm 0.09^{\mathrm{a}}$ & $6.28 \pm 1.00$ \\
\hline CLRG & $11.21 \pm 0.18^{\mathrm{f}}$ & $3.12 \pm 0.98$ \\
\hline CLRL & $13.68 \pm 0.50^{\mathrm{e}}$ & $4.34 \pm 1.00$ \\
\hline CLRS & $15.02 \pm 0.04^{\mathrm{d}}$ & $6.92 \pm 0.98$ \\
\hline
\end{tabular}

Total polyphenols were expressed as equivalent $\mathrm{mg}$ of chlorogenic acid (CAE). Total flavonoids were expressed as equivalent $\mathrm{mg}$ of quercetin $\mathrm{mg}(\mathrm{QE})$.Values $(\mathrm{n}=3) \pm \mathrm{SE}$ with different letters within the same column are significantly different at $p<0.05$.

Regarding the values of total flavonoid, it was possible to appreciate how they are significantly higher in CLCR, compared to the CLKR ones (Table III). The results are in line with what previously demonstrated by other authors [14, 34]. For the Romanian yellowfleshed watermelons (CLRG, CLRL, CLRS, collected in June, July and September, respectively) for which it was possible to monitor the phenophase, and therefore the balsamic time (when phytochemical reach their maximum concentrations), the increasing content in polyphenols and flavonoids is highlighted (Table III). However, the therapeutic effects recognized to $C$. lanatus are certainly attributable to the antioxidant activity conferred by the phenols but above all to lycopene $[8,26,47]$. This compound plays a fundamental role in the treatment of cardiovascular diseases [40] and in the management of hyperglycaemia $[2,19]$, and it is involved in the onset of metabolic syndrome (MetS). From the data obtained, it emerges that lycopene content was significantly higher in South American watermelons (CLCR and CLE), whose content is almost twice the other samples (Table III), so explaining their intense red colour and antioxidant activity (Tables VI and VII). These relationships were highlighted by other authors $[13,30,44]$.

The antioxidant and anti-radical activities of carotenoids, lycopene, polyphenols and flavonoids, show protective effects against chronic diseases such as hyperglycaemic and hypercholesteraemic activity [1]. In Romanian watermelons (CLRG, CLRL, CLRS), lycopene content grew linearly during the phenophase, but it was significantly lower than that found in other watermelons (Table III), giving to the fruit the typical golden yellow colour.

From the analysis of the antioxidant activity of watermelon pulp, it was possible to find positive correlations of DPPH• (Table IV) with polyphenols and lycopene contents (Table III). Noteworthy, the antioxidant activity in the Romanian watermelons (CLRL and CLRS) remained significantly unchanged during the ripening period between July and September (Table IV), despite both the contents of lycopene and polyphenols increased (Table III).

Table IV

Total phenols and total antioxidant activity determined by $\mathrm{DPPH} \bullet$ radical scavenging activity

\begin{tabular}{|l|c|c|}
\hline Sample & $\begin{array}{c}\text { Total phenols } \\
(\mathbf{m g} \text { CAE/g FW })\end{array}$ & $\begin{array}{c}\text { DPPH• }\left(\mathbf{I C}_{\mathbf{5 0})}\right) \\
(\boldsymbol{\mu g} / \mathbf{m L})\end{array}$ \\
\hline CLB & $14.98 \pm 0.13^{\mathrm{c}}$ & $2.68 \pm 0.57^{\mathrm{b}}$ \\
\hline CLCR & $16.07 \pm 0.09^{\mathrm{b}}$ & $0.60 \pm 0.41^{\mathrm{d}}$ \\
\hline CLE & $17.50 \pm 0.32^{\mathrm{a}}$ & $0.64 \pm 1.08^{\mathrm{d}}$ \\
\hline CLL & $16.73 \pm 0.80^{\mathrm{b}}$ & $1.73 \pm 0.58^{\mathrm{c}}$ \\
\hline CLLM & $15.84 \pm 0.15^{\mathrm{b}}$ & $1.52 \pm 0.44^{\mathrm{c}}$ \\
\hline CLKR & $18.70 \pm 0.09^{\mathrm{a}}$ & $1.42 \pm 0.99^{\mathrm{c}}$ \\
\hline CLRG & $11.21 \pm 0.18^{\mathrm{d}}$ & $3.82 \pm 1.03^{\mathrm{a}}$ \\
\hline CLRL & $13.68 \pm 0.50^{\mathrm{cd}}$ & $3.61 \pm 0.99^{\mathrm{a}}$ \\
\hline CLRS & $15.02 \pm 0.04^{\mathrm{c}}$ & $3.62 \pm 0.83^{\mathrm{a}}$ \\
\hline
\end{tabular}

Values $(n=3) \pm$ SE with different letters within the same column are significantly different at $\mathrm{p}<0.05$. For the positive control, Trolox was used.

As demonstrated by Jaskani et al. [21] and Zhao et al. [49], for yellow-fleshed watermelons the lycopene content was significantly lower (Table III) and associated to a reduced anti-peroxyl activity detected through the $\beta$-carotene bleaching test (Table V). The antioxidant activity was lost after $60 \mathrm{~min}$ of heat treatment (Table V). Thus, the differing trend of antioxidant activity in the different watermelon varieties (Table V) can be explained by the different composition 
FARMACIA, 2020, Vol. 68, 4

of the polyphenolic fraction and for the lycopene

content (Table III).

Table V

Lycopene and total antioxidant activity determined by $\beta$-carotene bleaching test in watermelon pulp

\begin{tabular}{|l|c|c|c|}
\hline Sample & $\begin{array}{c}\text { Lycopene } \\
(\boldsymbol{\mu g} / \mathbf{g} \mathbf{F W})\end{array}$ & $\begin{array}{c}\boldsymbol{\beta} \text {-carotene 30' } \\
(\boldsymbol{\mu g} / \mathbf{m L})\end{array}$ & $\begin{array}{c}\boldsymbol{\beta} \text {-carotene 60' } \\
(\boldsymbol{\mu} \mathbf{g} / \mathbf{m L})\end{array}$ \\
\hline CLB & $19.00 \pm 0.24^{\mathrm{c}}$ & $\left.54.5 \pm 0.05^{\mathrm{d}}\right)$ & $99.96 \pm 0.07^{\mathrm{c}}$ \\
\hline CLCR & $39.68 \pm 0.13^{\mathrm{a}}$ & $28.4 \pm 0.50^{\mathrm{f}}$ & $93.44 \pm 0.11^{\mathrm{d}}$ \\
\hline CLE & $28.28 \pm 0.45^{\mathrm{b}}$ & $30.8 \pm 0.26^{\mathrm{f}}$ & $94.95 \pm 0.30^{\mathrm{d}}$ \\
\hline CLL & $18.08 \pm 0.58^{\mathrm{c}}$ & $34.2 \pm 0.13^{\mathrm{f}}$ & $91.91 \pm 0.99^{\mathrm{d}}$ \\
\hline CLLM & $17.70 \pm 0.11^{\mathrm{cd}}$ & $62.5 \pm 0.35^{\mathrm{c}}$ & $115.96 \pm 0.47^{\mathrm{b}}$ \\
\hline CLKR & $15.09 \pm 0.37^{\mathrm{d}}$ & $48.5 \pm 1.00^{\mathrm{e}}$ & $99.94 \pm 0.11^{\mathrm{c}}$ \\
\hline CLRG & $6.21 \pm 0.88^{\mathrm{eh}}$ & $71.2 \pm 0.98^{\mathrm{b}}$ & $133.22 \pm 1.03^{\mathrm{a}}$ \\
\hline CLRL & $8.68 \pm 0.23^{\mathrm{e}}$ & $99.4 \pm 1.00^{\mathrm{a}}$ & $132.61 \pm 0.99^{\mathrm{a}}$ \\
\hline CLRS & $9.02 \pm 0.50^{\mathrm{e}}$ & $99.2 \pm 0.98^{\mathrm{a}}$ & $132.02 \pm 0.83^{\mathrm{a}}$ \\
\hline
\end{tabular}

Values $(n=3) \pm \mathrm{SE}$ with different letters within the same column are significantly different at $\mathrm{p}<0.05$. For the positive control, Trolox was used.

The results on phenols, flavonoids and lycopene content in $C$. lanatus pulp extraction (Table III) reveals how, on one hand, this fruit is ascribable to the list of seasonal foods recommended for the intake of phytocomplexes, antioxidants and nutrients [45], on the other hand, that it is an interesting source of citrulline $[16,39]$. Indeed, the collected data indicate a higher content of L-citrulline in rind samples of watermelon from Brazil (CLB) and Ecuador (CLE), as well as of those of Italian origin and grown in Latina (CLL) and Lamezia Terme (CLLM) (Table VI).

Table VI

L-citrulline content in watermelon pulp and rind

\begin{tabular}{|l|c|c|}
\hline & \multicolumn{2}{|c|}{ L-citrulline } \\
\hline Sample & (mg/g FW pulp) & (mg/g FW rind) \\
\hline CLB & $0.38 \pm 0.09^{\mathrm{d}}$ & $2.60 \pm 0.12^{\mathrm{a}}$ \\
\hline CLCR & $0.38 \pm 0.11^{\mathrm{d}}$ & $1.87 \pm 0.01^{\mathrm{c}}$ \\
\hline CLE & $0.87 \pm 0.03^{\mathrm{a}}$ & $2.32 \pm 0.03^{\mathrm{b}}$ \\
\hline CLL & $0.47 \pm 0.07^{\mathrm{b}}$ & $2.31 \pm 0.17^{\mathrm{b}}$ \\
\hline CLLM & $0.10 \pm 0.02^{\mathrm{f}}$ & $2.33 \pm 0.17^{\mathrm{b}}$ \\
\hline CLKR & $0.51 \pm 0.28^{\mathrm{c}}$ & $1.31 \pm 0.04^{\mathrm{d}}$ \\
\hline CLRG & $0.25 \pm 0.03^{\mathrm{e}}$ & $0.71 \pm 0.09^{\mathrm{e}}$ \\
\hline CLRL & $0.11 \pm 0.09^{\mathrm{f}}$ & $0.68 \pm 0.03^{\mathrm{e}}$ \\
\hline CLRS & $0.02 \pm 0.03^{\mathrm{g}}$ & $0.12 \pm 0.05^{\mathrm{f}}$ \\
\hline
\end{tabular}

Values $(n=3) \pm$ SE with different letters within the same column are significantly different at $\mathrm{p}<0.05$.

Noteworthy was the detection of L-citrulline in the pulp extracts of CLE, CLKR and CLL watermelons, as this compound is mainly concentrated in the inner rind $[36,39]$. This result is particularly relevant for the purpose of the work, as citrulline, known to exert a vascular endothelial protection, could be extracted from the pulp, even if in a significantly reduced quantity, compared to the rind.

Enzymatic assays

Considering its nutritional profile, the consumption of $100 \mathrm{~g}$ of watermelon provides $16 \mathrm{kcal}$, and this amount contains approximately $94 \%$ water and $3.7 \%$ carbohydrates available, with $0.4 \%$ fibres $(0.02 \%$ soluble), $280 \mathrm{mg}$ of potassium and $8 \mathrm{mg}$ of $\mathrm{C}$ vitamin [33]. Moreover, the pulp does not contain lipids and therefore watermelon is defined as a low-calories fruit [7, 24].

In this research, the pulp samples, despite the peculiar antioxidant activities shown through the DPPH• and BCB tests (Tables VI and VII), show significant inhibition activity for lipase and $\alpha$-amylase, compared to the orlistat and acarbose control, respectively (Table VII).

Table VII

Inhibition of lipase and $\alpha$-amylase in watermelon

\begin{tabular}{|l|c|c|}
\hline Sample & Lipase $\left(\mathbf{I C}_{\mathbf{5 0}}\right)^{*}$ & $\boldsymbol{\alpha}$-amylase $\left(\mathbf{I C}_{\mathbf{5 0}}\right)^{* * *}$ \\
\hline CLB & $143.36 \pm 1.52^{\mathrm{e}}$ & $186.12 \pm 0.75^{\mathrm{d}}$ \\
\hline CLCR & $137.50 \pm 0.70^{\mathrm{f}}$ & $171.37 \pm 0.35^{\mathrm{e}}$ \\
\hline CLE & $130.55 \pm 0.28^{\mathrm{fg}}$ & $184.40 \pm 0.40^{\mathrm{d}}$ \\
\hline CLL & $126.57 \pm 0.71^{\mathrm{g}}$ & $169.70 \pm 0.58^{\mathrm{e}}$ \\
\hline CLLM & $166.78 \pm 0.35^{\mathrm{d}}$ & $176.33 \pm 0.84^{\mathrm{de}}$ \\
\hline CLKR & $117.10 \pm 0.19^{\mathrm{h}}$ & $145.52 \pm 0.50^{\mathrm{f}}$ \\
\hline CLRG & $312.12 \pm 0.98^{\mathrm{a}}$ & $322.13 \pm 1.03^{\mathrm{a}}$ \\
\hline CLRL & $234.64 \pm 1.00^{\mathrm{b}}$ & $261.36 \pm 1.01^{\mathrm{b}}$ \\
\hline CLRS & $192.45 \pm 0.98^{\mathrm{c}}$ & $202.42 \pm 0.83^{\mathrm{c}}$ \\
\hline
\end{tabular}
pulp

Values $(n=3) \pm$ SE with different letters within the same column are significantly different at $\mathrm{p}<0.05$.

* = lipase expressed as $\mathrm{IC}_{50}$ concentration; lipase positive control: orlistat $\mathrm{IC}_{50}=57.20 \pm 0.19 \mu \mathrm{g} / \mathrm{mL}$. $* *=\alpha$-amylase expressed as $\mathrm{IC}_{50}$ concentration, i.e. the concentration of extract in $\mu \mathrm{g} / \mathrm{mL}$ which inhibits the enzymatic activity by $50 \%$; $\alpha$ amylase positive control: acarbose $\mathrm{IC}_{50}=36.50 \pm 0.32 \mu \mathrm{g} / \mathrm{mL}$.

The inhibition was particularly higher in the Romanian watermelons (Table VII). Human pancreatic amylase with 496-amino acid sequence of shows $83 \%$ identity with that of porcine amylase [35]. The inhibition of amylases has been demonstrated, contributing to the reduction of digestion of sugars in the intestinal lumen and, therefore, able to slow down the absorption of glucose and its consequent increase in plasma [15]. Our results are particularly interesting when viewed from the perspective of the clinical management of the diabetic patients for whom, usually, watermelon is strongly discouraged in dietary integration.

The second enzyme here analysed, lipase, is secreted in the duodenum through the pancreatic duct and is responsible for $50 \%-70 \%$ of the total hydrolysis of 
FARMACIA, 2020, Vol. 68, 4

food fats. The active ingredients able to inhibit lipases, enzymes dedicated to the hydrolysis of food fats, play a particularly important role in the pharmacological treatment of obesity. These compounds are involved in the first step of the metabolism of fatty acids, inhibiting their intestinal absorption and their accumulation by the body [5]. The control compound, orlistat, has a structure very similar to triglycerides, for which the lipase has great affinity. Therefore, a very stable link between orlistat and lipase is created, so as not to allow the reversibility of the phenomenon within the normal transit times of the intestinal bolus [12]. In this study, as for $\alpha$-amylase (Table VI), a significant lipase inhibition was observed for all the samples analysed and particularly for Romanian watermelons (Table VII).

The clinical practice advises against the consumption of watermelon in diabetic subjects because it is considered a food with a high glycaemic index (GI). The literature, however, demonstrated that watermelon has a low glycaemic index (Robert et al., 2008), as it contains a higher percentage of fructose $(16.4 \mathrm{~g} / 100 \mathrm{~g})$ which has a lower GI $(19 \pm 2)$ than glucose (content = $9.3 \mathrm{~g} / 100 \mathrm{~g}$, with an $\mathrm{IG}=99 \pm 3$ ) and that, before entering the bloodstream, must be converted into glucose from the liver [17].

\section{Conclusions}

In this study, it was decided to investigate the peculiarities of watermelon pulp because it is the part intended for human consumption, and due to its high content of antioxidants (e.g., lycopene) and bioactive molecules (e.g., citrulline), as here demonstrated. Furthermore, the comparisons between different watermelons with different origins revealed the significant inhibitory action on both $\alpha$-amylase and lipase, so confirming that the health-promoting potential of their consumption. All these factors taken together make watermelon a high-value food with evident benefits on human health.

\section{Conflict of interest}

The authors declare no conflict of interest.

\section{References}

1. Abirami A, Nagarani $G$, Siddhuraju $P$, In vitro antioxidant, anti-diabetic, cholinesterase and tyrosinase inhibitory potential of fresh juice from Citrus hystrix and $C$. maxima fruits. Food Sci Hum Wellness, 2014; 3: $16-25$.

2. Akilandeswari V, Karthikeyan S, Vasanth S, Elavarasi $\mathrm{P}$, Study on antihyperglycemic effect of lycopene in alloxan induced diabetes in rats. Intern J Sci Res., 2016; 5(11): 244-246.

3. Aruna A, Vijayalakshmi K, Karthikeyan V, Pancreatic lipase inhibitory screening of Citrullus lanatus leaves. Pharma Innovat., 2014; 3(7): 44-52.
4. Bendicho S, Trigueros MC, Hernández T, Martin O, Validation and comparison of analytical methods based on the release of p-nitrophenol to determine lipase activity in milk. J Dairy Sci., 2001; 84(7): 1590-1596.

5. Birari RB, Bhutani KK, Pancreatic lipase inhibitors from natural sources: unexplored potential. Drug Discovery Today, 2007; 12(19-20): 879-889.

6. Bredt DS, Snyder SH, Nitric oxide: a physiologic messenger molecule. Annual Rev Biochem., 1994; 63: 175-195.

7. Bruton BD, Fish WW, Roberts W, Popham TW, The influence of rootstock selection on fruit quality attributes of watermelon. Open Food Sci J., 2009; 3: 15-34.

8. Charoensiri R, Kongkachuichai R, Suknicom S, Sungpuag P, Beta-Carotene, lycopene and alphatocopherol contents of selected Thai fruits. Food Chem., 2009; 113: 202-207.

9. Cheng ZQ, Liu WG, Deng Y, Zhao SJ, Yan ZH, He $\mathrm{N}$, Extraction and determination of L-citrulline in watermelon fruits. J Fruit Sci., 2010; 27(4): 650-654.

10. Choudhary BR, Haldhar SM, Maheshwari SK, Bhargava $\mathrm{R}$, Sharma SK, Phytochemicals and antioxidants in watermelon (Citrullus lanatus) genotypes under hot arid region. Ind J Agric Sci., 2015; 85(3): 414-417.

11. Davis AR, Fish AW, Perkins-Veazie P, A rapid spectrophotometric method for analyzing lycopene content in tomato and tomato products. Postharvest Biol Technol., 2003; 28(3): 425-430.

12. De Cristofaro $P$, Methodological basis of the Psychonutritional Approach. See Publishing, Florence, Italy, 2002, (available in Italian).

13. Dembinska-Kiec A, Mykkanen O, Kiec-Wilk B, Mykkanen H, Antioxidant phytochemicals against type 2 diabetes. Brit J Nutrit., 2008; 991: S109-S117.

14. Dieng SIM, Diallo AJ, Fall AD, Diatta-Badji K, Diatta W, Sarr A, Bassene E, Total polyphenols and flavonoids contents of aqueous extracts of watermelon red flesh and peels (Citrullus lanatus, Thunb). J Pharmacog Phytochem., 2017; 6(5): 801-803.

15. El-Beshbishy HA, Bahashwan SA, Hypoglycemic effect of basil (Ocimum basilicum) aqueous extract is mediated through inhibition of $\alpha$-glucosidase and $\alpha$-amylase activities: An in vitro study. Toxicol Ind Health, 2012; 28(1): 42-50.

16. Figueroa A, Wong A, Jaime SJ, Gonzales JU, Influence of L-citrulline and watermelon supplementation on vascular function and exercise performance. Cur Opin Clin Nutrit Metab Care, 2017; 20(1): 92-98.

17. Foster-Powell K, Holt SH, Brand-Miller JC, International table of glycemic index and glycemic load values. Am J Clin Nutrit., 2002; 76: 5-56.

18. Furchgott RF, Zawadzki JV, The obligatory role of endothelial cells in the relaxation of arterial smooth muscle by acetylcholine. Nature, 1980; 288: 373-376.

19. Haribabu T, Divakar K, Goli D, Evaluation of antidiabetic activity of lycopene and its synergistic effect with metformin hydrochloride and glipizide in alloxan induced diabetes in rats. Schol Acad J Pharm (SAJP), 2013; 2(2): 119-124.

20. Hassan LEA, Sirat HM, Yagi SMA, Waleed SK, Siddig IA, In-vitro antimicrobial activities of chloroformic, 
hexane and ethanolic extracts of Citrullus lanatus var citroides. J Medicin Plants Res., 2011; 5(8): 1338-1344.

21. Jaskani MJ, Kwon SW, Kim DH, Comparative study on vegetative, reproductive and qualitative traits of seven diploid and tetraploid watermelon lines. Euphytica, 2005; 145(3): 259-268.

22. Kwon YI, Apostolidis E, Kim YC, Shetty K, Health benefits of traditional corn, beans and pumpkin: In vitro studies for hyperglycemia and hypertension management. J Med Food, 2007; 10: 266-275.

23. Lebeda A, Widrlechner MP, Staub J, Ezura H, Zalapa J, Kristkova E, Cucurbits (Cucurbitaceae; Cucumis spp, Cucurbita spp, Citrullus spp). NCRPIS Publications and Papers, 2007; 3: 271-386.

24. Leskovar DI, Bang H, Crosby KM, Maness N, Franco JA, Perkins-Veazie P, Lycopene, carbohydrates, ascorbic acid and yield components of diploid and triploid watermelon cultivars are affected by deficit irrigation. J Horticult Sci Biotech., 2004; 79: 75-81.

25. Levi A, Thomas CE, Keinayh AP, Wehner TC, Genetic diversity among watermelon (Citrullus lanatus and Citrullus colocynthis) accessions. Genet Resour Crop Evol., 2001; 48: 559-566.

26. Lewinsohn E, Sitrit Y, Bar E, Azulay Y, Ibdah M, Meir A, Yosef E, Zamir D, Tadnor Y, Not just colorscarotenoid degradation as a link between pigmentation and aroma on tomato and watermelon fruits. Trends Food Sci Tech., 2005; 16: 407-415.

27. Liu W, Zhao S, Cheng Z, Wan X, Yan Z, Lycopene and citrulline contents in watermelon (Citrullus lanatus) fruit with different ploidy and changes during fruit development. Acta Horticulturae (ISHS), 2010; 871: 543-550.

28. Lowe M, The triglyceride lipases of the pancreas. $J$ Lipid Res., 2002; 43: 2007-2016.

29. Marrelli M, Loizzo MR, Nicoletti M, Menechini F, Conforti F, In vitro investigation of the potential health benefits of wild Mediterranean dietary plants as anti-obesity agents with $\alpha$-amylase and pancreatic lipase inhibitory activities. J Sci Food Agric., 2014; 94: 2217-2224.

30. Mein JR, Lian F, Wang XD, Biological activity of lycopene metabolites: implications for cancer prevention. Nutrition Rev., 2008; 66(12): 667-683.

31. Morgovan C, Ghibu S, Juncan AM, Rus LL, Butucă A, Vonica L, Muntean A, Moş L, Gligor F, Olah NK, Nutrivigilance: A new activity in the field of dietary supplements. Farmacia, 2019; 67(3): 537-544.

32. Naz A, Butt MS, Pasha I, Nawaz H, Antioxidant indices of watermelon juice and lycopene extract. $\mathrm{Pak}$ J Nutrit., 2013; 12: 255-260.

33. Nweze CC, Abdulganiyu MG, Erhabor OG, Comparative analysis of vitamin $\mathrm{C}$ in fresh fruits juice of Malus domestica, Citrus sinensi, Ananascomosus and Citrullus lanatusby iodometric titration. Intern J Sci Environ Technol., 2015; 4(1): 17-22.
34. Olabinri BM, Olaleye MT, Ajani RA, Akinmayowa $\mathrm{S}$, Busayo OO, Funmilola A, In vitro discovery of watermelon (Citrullus lanatus) extract with moderate chelating ability, and survey of other in vitro bioactivities. Amer Intern J Contemp Res., 2013; 3(4): 140-149.

35. Pasero L, Pierron Y, Abadie B, Chicheportiche Y, Marchis-Mouren G, Complete amino acid sequence and location of the five disulfide bridges in porcine pancreatic $\alpha$-amylase. Biochimica et Biophysica Acta, 1986; 869: 147-157.

36. Rimando AM, Perkins-Veazie PM, Determination of citrulline in watermelon rind. $J$ Chromatography, 2005; 1078(1-2): 196-200.

37. Stancu E, Tăerel AE, Soroceanu V, Rais C, Ghica $\mathrm{M}$, Ethical aspects of food supplements in EU and Romania. Farmacia, 2019; 67(4): 736-742.

38. Sugiyama H, Akazome Y, Shoji T, Yamaguchi A, Yasue M, Kanda T, Ohtake Y, Oligomeric procyanidins in apple polyphenol are main active components for inhibition of pancreatic lipase and triglyceride absorption. J Agricult Food Chem., 2007: 55(11): 4604-4609.

39. Tarazona-Díaz MP, Viegas J, Moldao-Martinscand M, Aguayo E, Bioactive compounds from flesh and by-product of fresh-cut watermelon cultivars. $J \mathrm{Sci}$ Food Agricult., 2011; 91: 805-812.

40. Thies F, Mills LM, Moir S, Masson LF, Cardiovascular benefits of lycopene: fantasy or reality? Proceed Nutrit Soc., 2017; 76: 122-129.

41. Tlili I, Hdider C, Lenucci MS, Riadh I, Jebari H, Dalessandro G, Bioactive compounds and antioxidant activities of different watermelon [Citrullus lanatus (Thunb)] cultivars as affected by fruit sampling area. J Food Composit Anal., 2011; 24(3): 307-314.

42. Toma CC, Casacchia T, Don I, D'Ippolito C, Statti GA, New extraction technologies for Syringa vulgaris (Oleaceae) meristematic extracts. Revista de Chimie (Bucharest), 2017; 68(8): 1796-1798.

43. Uluturk IZ, Frary A, Doganlar S, Determination of genetic diversity in watermelon [Citrullus lanatus (Thunb) Matsum \& Nakai] germplasm. Am J Cult Soc., 2011; 5(13): 1832-1836.

44. Weberling A, Bohm V, Frohlich K, The relation between lycopene, tomato products and cardiovascular diseases. Agro Food Ind Hi-Tech, 2011; 22: 21-22.

45. Williamson G, Holst B, Dietary reference intake (DRI) value for dietary polyphenols: are we heading in the right direction?. Brit. J Nutrit., 2008; 99(3): S55-S58.

46. Wu G, Morris SM, Arginine metabolism: nitric oxide and beyond. Biochem J., 1998; 36: 1-17.

47. Yadav RNS, Agarwala M, Phytochemical analysis of some medicinal plants. J Phytology, 2011; 3: 10-14.

48. Yamaguchi M, World Vegetables: Principles, Production and Nutritive values. AVI Pub. Co., Westport, CT, USA, 1983.

49. Zhao W, Lv P, Gu H, Studies on carotenoids in watermelon flesh. Agricult Sci., 2013; 4(7A): 13-20. 